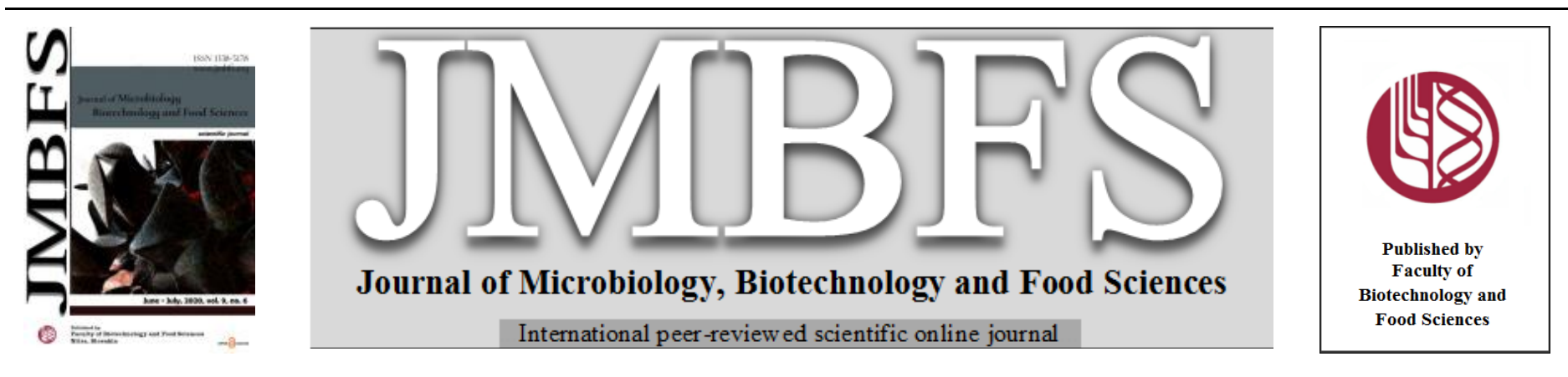

\title{
ANTIMICROBIAL POTENTIAL OF ZIZIPHUS AND EUPHORBIA HONEYS HARVESTED IN SEMI-ARID REGION OF ALGERIA AND THEIR POSSIBLE USE IN SOFT MEDICINE
}

\author{
Haderbache Latifa ${ }^{1 *}$, Annou Saada ${ }^{1}$, Mohammedi Arezki ${ }^{2}$ \\ Address(es): \\ ${ }^{1}$ Research laboratory in food technology (LRTA), M'hamed Bougara University, Avenue de l'indépendance, Boumerdes 35000, Algeria. \\ ${ }^{2}$ Research laboratory in conservation and valorization of biological resources (VALCORE), M'hamed Bougara University, Avenue de l'indépendance, Boumerdes \\ 35000 , Algeria.
}

*Corresponding author: 1.haderbache@univ-boumerdes.dz

doi: 10.15414/jmbfs.2020.9.6.1114-1118

ARTICLE INFO

Received 24. 4. 2019

Revised 21. 1. 2020

Accepted 4. 2. 2020

Published 1. 6. 2020

Regular article

OPEN $\partial_{\text {ACCESS }}$

\begin{abstract}
Two different botanical origin honey types (Ziziphus lotus and Euphorbia bupleuroides) from semi-arid regions in Algeria consisting of twelve samples were tested for their antimicrobial efficiency. Global assessment of antimicrobial activity was made by wells method on integer samples and by turbidity test to locate fraction responsible of this activity. Honeys have been tested against Escherichia coli, Staphylococcus aureus, Pseudomonas aeruginosa and Candida albicans. Fungal strain was resistant to all honeys at all concentrations, whereas E. coli and S. aureus were sensitive presenting minimum inhibition concentrations (MIC) between 10 and 50\%. Euphorbia honeys appeared to be more active. The fractionation shows that volatile fraction can have great antimicrobial effect, followed by the acidic one. Correlations reveal good relation between inhibitory effect, free acidity and polyphenols. These facts show large possibilities for honey use in soft medicine against some bacterial infections.
\end{abstract}

Keywords: Honey; Ziziphus lotus; Euphorbia bupleuroides; Antimicrobial activity; soft medicine; Algeria

\section{INTRODUCTION}

The honey efficiency is well known, since long centuries, against the infectious illnesses provoked by several strains such as: Staphylococcus aureus, Salmonella typhi, Campylobacter, Escherichia coli, Listeria monocytogenese (Brasson and Gobler, 2008, Lin et al., 2009, Zahoor et al., 2014). It has been signaled to be active on more than 60 bacteria species (aerobes and anaerobes, Gram positive and Gram negative), a fungicidal effect has also been signaled on some yeast and Aspergillus and Penicillium species (Molan, 1992a), as well as on all common dermatophytes (Brady et al., 1997).

Several intrinsic factors participate to this anti-microbial activity; as osmolarity, acidity, viscosity, $\mathrm{H}_{2} \mathrm{O}_{2}$, non-peroxides inhibines as lyzozymes, flavonoides, acidic phenols, and aromatic acids (Bogdanov and Blumer, 2001). Bogdanov (Bogdanov, 1997b) suggests that non-peroxide inhibines depend on the botanical origin of honey, but can come from the bee herself, these molecules have been classified in four groups: neutral, acidic, basic and volatile (Bogdanov, 1997b) however, it is the acidic fraction that had the most marked activity for studied blossom and honeydew honeys (Bogdanov et al., 2008). This activity depends as well on conditioning methods and storage conditions (Salomon, 2010).

Several studies made relation between this AMA (anti-microbial activity) and the floral origin of some honeys (Conifers honeydew, Castanea sativa and Manuka honeys, etc.). The relation of this activity with the dark color has always been signaled (Dustman, 1979), but the variations are so big that it is very difficult to make some associations, unless a large number of honey samples are investigated with established floral origin, on several harvests, of several years (Molan, 1992b, Moniruzzaman et al., 2013). Other authors correlated AMA with phenolic compounds and especially flavonoids(Je-Ruei et al., 2013, Escriche $\boldsymbol{e t}$ $\boldsymbol{a l} ., \mathbf{2 0 1 4}$ ) or with proteins present in the digestive tube of bees (Mundo $\boldsymbol{e t} \boldsymbol{a l}$., 2004).

Researches about antimicrobial activity of honeys, currently have a very big interest because they are becoming used more frequently in the medical domain where medicines do not manage to achieve hoped results, as in the case of the pathogenic strains resistance to various medicinal treatments, we give for example the case of $S$. aureus and Helicobacter pylori isolated from gastric ulcers or infected burns (Al Somal et al., 1994, Cooper, 2001, Cooper et al., 2002b, Willix et al., 1992, Majtan et al., 2013), or Streptococcus mutans and Lactobacillus acidophilus incriminated in the occurrence of tooth decays (Patel et al., 2011, Jaganathan, 2011).
The new interest of Algerian consumer in honeys from semi-arid regions and for soft medicines is pushing scientist to make more investigations on this scope. Ziziphus lotus is Rhamnaceae shrub called "Sedra, N'beg, or Azar Djerdjer", it is widespread in our arid and semi-arid regions, akin to "sidr" in Middle East countries (Baba Aissa, 1999, Al Khalifa and Al Arify, 1999, Mekious et al., 2015, Zerrouk et al., 2017). Honey from this species was found to be different of common blossom honeys, with a very large shelf life and with particular richness in enzymes, polyphenols and antiradicalar activity (Haderbache et al., 2013). Whereas Euphorbia bupleuroides L. is an euphorbiaceae species called "Lebayna, Helayba, Halib elDiba, or tanahout", it is one of native Algerian plants, the most visited by bees among 51 euphorbia species known as toxic plants (Quezel and Médail, 2003). Its honey contains very high amount of flavonoids (Haderbache $\boldsymbol{e t}$ al., 2013). The same interest was showed for these two botanical families in morocco (Chakir et al., 2011).

The aim of this work is to quantify their antimicrobial activity against three bacterial strains (E. coli / G -; S. aureus/G+ and P. aeruginosa /G -) and one fungal strain (C. albicans), often incriminated in human pathologies. Honeys fractionation in four groups (volatile, neutral, acidic and basic) will enable to identify the nature of active molecules. Until this day no work has been done on the antimicrobial activity of such kinds of honeys, although they are widely used in Maghreb traditional therapy (Sedative and immune-modulatory virtues; Light laxative effect; Hypotensive and anti-diabetic potential; Anti-inflammatory; Emollient and bechic).

\section{MATERIAL AND METHODS}

\section{Botanical and biological material}

The experimentation involved twelve samples of honey from two botanical origins namely Ziziphus lotus and Euphorbia bupleuroides, provided by professional apiarists. Samples were harvested in different regions (El Bayadh, Aflou, Laghouat, Ain safra) and on different years (2009 to 2012); The chosen acceptance criteria were: Fresh harvested honeys, known harvesting area, Ziziphus lotus and Euphorbia buplorö̈des supposed honey kind, organoleptic properties reminding the mentioned floral source, sufficient quantity for all analysis and the use of virgin honey combs just before harvest to avoid residue transfer if any. Chosen strains are generally used in testing antimicrobial honey effects: Escherichia coli (ATCC 25922), Staphylococcus aureus (ATCC 25923), 
Pseudomonas aeruginosa (ATCC 9027) and Candida albicans (ATCC 10231) were reference strains, procured from research center \& development of SAIDAL (Algerian pharmaceutic laboratory).

\section{Pollinic and physic-chemical analyzes}

The floral origin has been confirmed by pollinic analysis based on harmonized methods of melissopalynology (Von der Ohe et al., 2004), Since Ziziphus and Euphorbia honeys are normally represented in pollens, the inclusion criteria was a percentage of the main pollen above $45 \%$ based on 1000-1200 counted and identified pollens. Total phenols and flavonoids have been achieved according to method described by Meda, Lamien (Meda et al., 2005). For polyphenols, the quantification is based on the reduction of phosphotungstic and green color phosphomolibdic mixture in molybdenum tungsten oxide of blue color, tests are made on $10 \%$ honey solution and coloration intensity is measured at $760 \mathrm{~nm}$ Lectures are reported on Gallic acid standard curve, and results expressed in Gallic acid Equivalent by $\mathrm{kg}$ of honey (mg EGA/kg). Whereas, flavonoids measurement is based on their complexation by aluminum trichlorure. The absorbance is read at $510 \mathrm{~nm}$ and the quantification made with Quercitine standard curve, results are expressed in Quercitine Equivalent by $\mathrm{kg}$ of honey (mg EQ/kg). Free acidity (FA) is measured by titration until $\mathrm{pH} 8.3$ and diastase activity (DN) by following-up the deterioration of the soluble starch through time (Official methods of the IHC)(Bogdanov, 1997a, Kumar et al., 2018).

\section{Global antimicrobial activity}

Global assessment of antimicrobial activity was made by wells method: it has been achieved by gelose diffusion technique (Marghitas $\boldsymbol{e t}$ al., 2009). Honeys solutions were prepared in normal saline water $(0.85 \%$ of salt), in different concentrations: $10 \%, 25 \%, 50 \%$ and $75 \%$. The sensitivity profile is determined by inhibition diameters measurements and MIC (Minimum inhibition concentration) is determined for each honey type. The sensitivity approach is inspired from the works of Meena and sethi (Meena and sethi, 1994) and Abou Ela, El sher (Aboul Ela et al., 1996), who qualify a strain as: Non inhibitory so $\varnothing$ $<7 \mathrm{~mm}$, Slightly inhibitory if $7 \mathrm{~mm}<\varnothing<13 \mathrm{~mm}$, Moderately inhibitory if $13 \mathrm{~mm}$ $<\varnothing<25 \mathrm{~mm}$ and Greatly inhibitory so $\varnothing>25 \mathrm{~mm}$.

Initially, before the antimicrobial test, strains are revivified by stripes dispersion on gelose surface, previously melted then cooled (nourishing gelose for bacteria and Sabouraud or OGA for fungous strains), followed by an incubation of $37^{\circ} \mathrm{C} / 24 \mathrm{~h}$ for bacteria and $25^{\circ} \mathrm{C} / 48 \mathrm{~h}$ to 5 days for yeasts. Strains purity is verified by microscopic test (Gram, shape, gathering and mobility) and standard microbial suspensions are prepared in sterile physiological water to get absorbance (at $520 \mathrm{~nm}$ ) between 0.22 and 0.32 for bacteria and between 2 and 3.8 for yeasts that correspond to a cell concentration of $10^{6}-10^{8} \mathrm{CFU} / \mathrm{ml}$ (Leclerc $\boldsymbol{e}$ al., 1993).

\section{Evaluation of antimicrobial activity of volatile, neutral, basic and acidic fractions}

Honeys are first heated at $70^{\circ} \mathrm{C}$ during $1 \mathrm{~h}$ (Bogdanov and Blumer, 2001) to destroy glucose-oxydase responsible of peroxide production, this precaution is taken to avoid mistakes in non-peroxide AMA evaluation. Fractionation and turbidity test are achieved according to the method described by Bogdanov (1997b); the volatile fraction is separated by rotavapory on $20 \%$ phosphate buffered honey solution, the neutral fraction by passage on a meadow full activated $\mathrm{C} 8$ column, the basic fraction by passage on a strong $\mathrm{HCl}$ activated cation exchange resin and finally the acidic fraction on a strong $\mathrm{NaOH}$ activated exchange resin, to avoid the influence of concentration and acidity, we readjust the fractions to initial Brix by adding or removing water (under vacuum) and $\mathrm{pH}$ to the initial value pHi. A SHIMADZU UV-1800 spectrophotometer is used for measuring the absorbance (A) at $520 \mathrm{~nm}$. The sealed glass tubes of $1 \mathrm{~cm}$ of diameter are used and placed directly on the optic ride of the device after incubation and correct mixing.

The relative inhibition percentage of a fraction is not directly measured but deduced from remaining fractions after each step and calculated by these formulas:

$\begin{array}{ll}\Delta \mathrm{A}=\mathrm{A} 2-\mathrm{A} 1 & \text { (Eq. 1) } \\ \mathrm{G}[\%]=100 * \Delta \mathrm{A} / \mathrm{A} 2 & \text { (Eq. 2) } \\ \mathrm{I}[\%]=100-\mathrm{G} & \text { (Eq. 3) } \\ \mathrm{If}=\text { If(n+1)-If(n-1) } & \text { (Eq. 4) }\end{array}$

Where: $\mathrm{A}$ is the absorbance, A2 the absorbance after incubation, A1 absorbance before incubation, $G$ growth rate, I inhibition rate, If inhibition rate of a fraction, If $(n+1)$ inhibition rate in the step after, If(n-1) inhibition rate in the step before.

\section{Evaluation of osmolarity, $\mathrm{pH}$ and $\mathrm{H}_{2} \mathrm{O}_{2}$ contribution in antimicrobia activity}

To evaluate osmolarity effect, artificial honeys are prepared based on global sugar composition and rotatory characteristics of each type of honey by mixing different proportions of fructose, glucose, maltose, $\mathrm{KCl}$ and water. There AMA is measured by turbidity test (in liquid medium).

The peroxide effect is estimated by comparing heated $\left(70^{\circ} \mathrm{C} / 1 \mathrm{~h}\right)$ and non-heated honey treated the same in a solution incubated at $37^{\circ} \mathrm{C}$ for $1 \mathrm{~h}$. Buffered honey solutions $(\mathrm{pH} 7, \mathrm{pH} 9$ and $\mathrm{pH} 3)$ where compared to water treated honey to show $\mathrm{pH}$ influence. For all experiences the solution concentration was the same (50\%) to avoid concentration effect.

Bactericidal and bacteriostatic effect

This test is based on a comparison between the absorbance of a yet inoculated and incubated 50\% honey solution like used in total AMA and the same solution added by physiological serum and re-incubated for $24 \mathrm{~h}(\mathrm{G}+)$ or $48 \mathrm{~h}(\mathrm{G}-)$ at $37^{\circ} \mathrm{C}$. Bactericidal effect is noted when there are no significant changes in $\mathrm{A}(<2 \%)$ and bacteriostatic one when there is an increase of bacterial growth $(>30 \%)$. The Concentration is preserved.

\section{Statistical analyzes}

The comparison between groups averages has been achieved by the test (coefficient of Pearson to $\mathrm{p}<0.05$ ) by statistical software SPSS17.0.

\section{RESULTS AND DISCUSSION}

Total polyphenols content of studied samples oscillates between 474 and 898 mg EGA/kg, while Flavonoïds ranged between 29 and $3213 \mathrm{mg} \mathrm{EQ} / \mathrm{kg}$ Flavonoïds/polyphenols ratio indicates that Ziziphus honeys are poorer in flavonoïds but richer in total phenols than Euphorbia ones.

Ziziphus samples show weak free acidities of $120 \pm 21 \mathrm{meq} / \mathrm{kg}$, an important quality that encourage a slow ageing, whereas euphorbia honeys are more acidic with an average of $208 \pm 57 \mathrm{meq} / \mathrm{kg}$. Diastase activity, being very important in the assessment of honeys health effects and freshness, reveals that Ziziphus honeys have more homogeneous DN values. There were no statistical differences between Ziziphus and Euphorbia groups for all parameters except for free acidity.

Table 1 summarize studied parameters generally related to antimicrobial effect (Total polyphenols, poly.; flavonoids, flav. ; free acidity, FA.; and Diastase activity, DN).

Table 1 Polyphenols, flavonoids, free acidity and diastase number results, sorted by botanical origin.

\begin{tabular}{|c|c|c|c|c|c|c|}
\hline Botanical origin group & Statistic & $\begin{array}{l}\text { Poly. } \\
{\left[\text { mgEGA } \cdot \mathrm{kg}^{-1}\right]}\end{array}$ & $\begin{array}{l}\text { Flav. } \\
{\left[\mathrm{mg} \mathrm{EQ} \cdot \mathrm{kg}^{-1}\right]}\end{array}$ & $\begin{array}{l}\text { Flav/ } \\
\text { poly } \\
{[\%]}\end{array}$ & $\begin{array}{l}\text { FA } \\
{\left[\mathrm{meq} \cdot \mathrm{kg}^{-1}\right]}\end{array}$ & $\begin{array}{l}\text { DN } \\
\text { [U shade] }\end{array}$ \\
\hline Euphobia & Mean \pm SD & $552 \pm 56^{\mathrm{a}}$ & $217 \pm 113^{\mathrm{a}}$ & $409 \pm 229$ & $208 \pm 57^{b}$ & $20.2 \pm 10.8^{\mathrm{a}}$ \\
\hline \multirow[t]{2}{*}{ Honeys $(n=6)$} & Min -max & 474- 639 & $59-313$ & $93-665$ & $160-320$ & $9.2-38.6$ \\
\hline & $\alpha(\%)$ & 10 & 52 & 56 & 27 & 53 \\
\hline Ziziphus & Mean \pm SD & $617 \pm 182^{\mathrm{a}}$ & $134 \pm 79^{\mathrm{a}}$ & $223 \pm 104$ & $120 \pm 21^{\mathrm{a}}$ & $23.2 \pm 7.4^{\mathrm{a}}$ \\
\hline \multirow[t]{2}{*}{ Honeys $(n=5)$} & Min - Max & $488-898$ & $29-250$ & $41-298$ & $100-150$ & $10.5-30$ \\
\hline & $\alpha(\%)$ & 30 & 59 & 46 & 18 & 32 \\
\hline
\end{tabular}

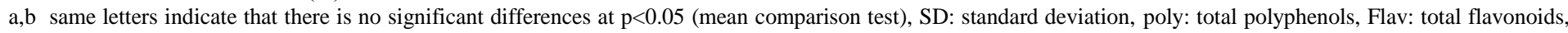
flav/poly: flavonoids polyphenols ratio, FA: free acidity, DN: diastase number, $\alpha(\%)$ : homogeneity coefficient.

Global antimicrobial activity

The study of global antimicrobial activities (table 2), show that C. albicans is resistant to Ziziphus and Euphorbia honeys at all concentrations for all samples. This result is in accordance with Zaghloul et al. (2001) who worked on Egyptian honeys. This fact it is not directly related to floral origin but probably due to the greatest tolerance of yeasts and fungal strains to concentrated medium which act only as bacteriostatic (Molan, 1992b), but it does not mean that it is true for all Candida strains and all honeys, many other authors demonstrated the sensitivity of different strains of Candida to Iranian and Indian honeys respectively with MIC about $24 \%$ (Revathy and Banerji, 1980, Khosvari et al., 2008). 
Table 2 Inhibition Diameters [mm] of Ziziphus and Euphorbia honeys (based on solution of 50\%).

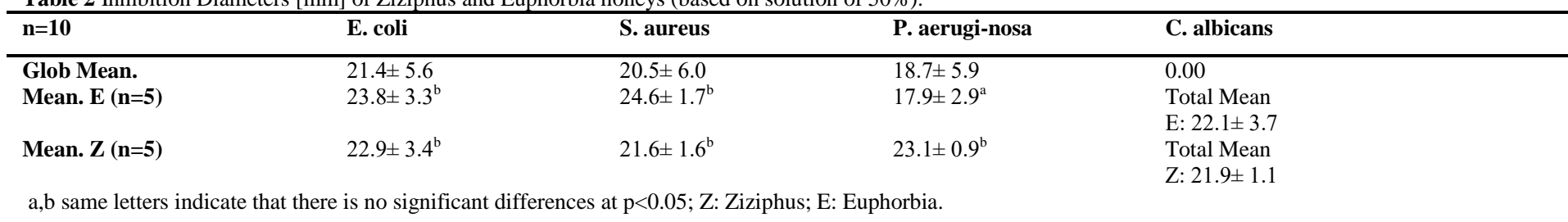

In parallel bacterial strains shows different sensitivity levels according to samples, but in general there were important inhibition of E. coli and S. aureus with average inhibition diameters of $21.4 \pm 5.6$ and $20.5 \pm 6.0 \mathrm{~mm}$ respectively. Euphorbia honeys shows moderate to strong AMA on $S$. aureus followed by $E$. coli and $P$. aeruginosa, whereas, Ziziphus honeys was the strongest against $P$. aeruginosa first, $E$. coli, then $S$. aureus; these results corroborate with investigations made Halawani and Shohayeb (2011) on Saudi Ziziphus "Shaoka and Sidr" honeys. It drives us to suppose that Euphorbia honeys are more efficient against Gram positive while Ziziphus against Gram negative strains.

Averages comparison, between both honey groups, by the $\mathrm{t}$ test, shows that they have comparable effects on $E$. coli and $S$. aureus but different for $P$. aeruginosa (Table 2). Generally, the AMA was more variable for E. coli than for the other strains.

The MIC for Euphorbia honeys oscillate between 10 and $25 \%$ with an average of $16 \%$ for E. coli, between 10 and $25 \%$ for S. aureus with an average of $20 \%$ and between 10 and $50 \%$ for P. aeruginosa with an average of $32 \%$. For Ziziphus the MIC averages are respectively of $16 \%, 46 \%$ and $32 \%$ for cited strains in this order. These observations drive us to say that Euphorbia honeys have better performances (dose/effect) against $S$. aureus.

\section{Antimicrobial activity of honey fractions}

The results of the fractionation test are represented in table 3. The AMA of whole honeys compared to an artificial one show that the osmotic effect can represen 10 to $36 \%$ of the global antimicrobial effect, with a range between 50 and $80 \%$, depending on strains sensitivity to medium concentration, a fact already reported by Bogdanov (1984). The antimicrobial effect within the same group changes from one year to another, it is probably due to the contribution of different plants nectars, knowing that every harvest honey is considered to be unique.

Table 3 Relative Inhibition Percentage of the Fractionated Honey Samples.

\begin{tabular}{|c|c|c|c|c|c|c|c|c|c|c|c|c|}
\hline \multirow[t]{2}{*}{ Honeys } & \multicolumn{12}{|c|}{ Relative inhibition of different fractions [\%] } \\
\hline & $\begin{array}{l}\text { Volatil } \\
\text { St. }\end{array}$ & Ps. & Ec. & $\begin{array}{l}\text { Neutral } \\
\text { St. }\end{array}$ & Ps. & Ec. & $\begin{array}{l}\text { Basic } \\
\text { St. }\end{array}$ & Ps. & Ec. & $\begin{array}{l}\text { Acidic } \\
\text { St. }\end{array}$ & Ps. & Ec. \\
\hline E2009 (n=2) & 2 & 57 & 3 & 90 & 3 & 1 & 1 & 4 & 3 & 7 & 36 & 93 \\
\hline $\mathrm{E} 2012(\mathrm{n}=2)$ & 86 & 84 & 90 & 3 & 2 & 0 & 6 & 2 & 8 & 14 & 17 & 3 \\
\hline $\mathrm{Z} 2010(\mathrm{n}=2)$ & 5 & 34 & 5 & 2 & 3 & 90 & 90 & 3 & 3 & 3 & 60 & 2 \\
\hline $\mathrm{Z} 2012(\mathrm{n}=2)$ & 90 & 80 & 74 & 4 & 2 & 2 & 5 & 13 & 2 & 1 & 5 & 22 \\
\hline Mean E $(n=4)$ & 44 & 71 & 47 & 47 & 3 & 1 & 4 & 3 & 6 & 11 & 27 & 48 \\
\hline Mean $Z(n=4)$ & 48 & 57 & 40 & 3 & 3 & 46 & 48 & 8 & 3 & 2 & 33 & 12 \\
\hline
\end{tabular}

St. : S. aureus ; Ps. : P. aeruginosa ; Ec. : E. coli ; E : Euphorbia honey ; Z : Ziziphus honey

The global antimicrobial effect survey of the different fractions show that the biggest part of AMA comes from the volatile fraction (>51\%); followed by the acidic one $(>22 \%)$ for euphorbia as well as for Ziziphus honeys. It comes to reinforce the observations of Bogdanov (1997b) who signaled important activity of the acidic fraction in some blossom honeys but he also affirms that it is very variable and can also be located in other fractions, for colza honey, it is the neutral fraction, whereas for honeydews it is rather in the basic fraction.

The studied microbial strains show clear differences in their reaction to honeys, $S$. aureus was sensitive to all fractions (volatile, basic and neutral) and slightly sensitive to the acidic one; $P$. aeruginosa was especially sensitive to volatile and acidic fractions, $E$. coli showed a comparable sensitivity for volatile and acidic, followed by neutral fraction but had no reaction to the basic one.

\section{Interrelationship between AMA and the Rates of Polyphenols, Flavonoids, FA and DN}

Since we noticed that the two types of honey have comparable effects on E. coli, which is a highly sensitive strain to bee products, we made this test to better identify the nature of active molecules. The survey of the existence of a global interrelationship between the AMA of E. coli on a honey solution of $75 \%$ (table 4), reveal that no statistically meaningful relation exists between this activity and the studied parameters, but the survey of honey groups apart shows that a strong relation exists between FA and AMA in Ziziphus honeys, proving that the active antimicrobial molecules are free acids but not polyphenols or flavonoids, whereas, for Euphorbia honeys Pearson criterion shows a slight relation with total polyphenols proving the role of phenolic acids but not of the flavonoids in Euphorbia honeys.

Table 4 Interrelationships between the AMA and Composition Parameters.

\begin{tabular}{|c|c|c|c|c|c|c|}
\hline & AMA & Poly. & Flav. & $\begin{array}{l}\text { Flav./ } \\
\text { poly. }\end{array}$ & FA & $\overline{\mathrm{DN}}$ \\
\hline \multirow{2}{*}{$\begin{array}{l}\text { All } \\
\text { samples }\end{array}$} & Cor. & -.087 & -.151 & -.157 & .215 & .089 \\
\hline & P. Sig. & .789 & .640 & .626 & .502 & .783 \\
\hline \multirow[t]{2}{*}{ E. } & Cor. & .509 & -0.189 & -0.301 & .160 & .151 \\
\hline & P. Sig. & .244 & .684 & .511 & .732 & .746 \\
\hline \multirow[t]{2}{*}{$\mathrm{Z}$. } & Cor. & -0.261 & -0.253 & -0.139 & $* .809$ & .032 \\
\hline & P. Sig. & .618 & .629 & .793 & .050 & .952 \\
\hline
\end{tabular}

*. The correlation is significant at p0.05 level (bilateral).

AMA: antimicrobial activity; Poly: polyphenols; Flav. Flavonoids; FA: free acidity; DN: diastase number. Flav./Poly.: ratio.P. Sig. :Pearson significance; Cor.: Correlation coefficient. E: euphorbia; z: ziziphus.

\section{Contribution of osmolarity, $\mathrm{pH}, \mathrm{H}_{2} \mathrm{O}_{2}$ in antimicrobial activity}

In this section, the global activity of the studied honeys is made with a turbidity test, to identify the peroxide, osmolarity and $\mathrm{pH}$ contribution in total honey AMA, as well as its nature (bactericidal or bacteriostatic).
According to the results shown in table 5, we can classify used strains from the most sensitive to least sensitive as follows: E. coli, S. aureus then P. aeruginosa. All strains show the greatest sensitivity to non-peroxide fraction, even if we know that E. coli and $S$. aureus are "catalase +" and are capable to inhibit the $\mathrm{H}_{2} \mathrm{O}_{2}$ produced in diluted honey by glucose oxidase enzyme, but according to 
Bogdanov and Blumer (2001), mature honeys only contain weak quantities of peroxide, weakly inhibiting bacterial growth and affirm that the mechanism of its

Table $5 \mathrm{pH}$, peroxide, non peroxyde and osmolarity Contribution in antimicrobial activity of Ziziphus and Euphorbia honeys.

\begin{tabular}{|c|c|c|c|c|c|c|c|c|}
\hline \multirow{2}{*}{$\begin{array}{l}\text { Relative } \\
\text { inhibition } \\
{[\%]}\end{array}$} & Total AMA & $\begin{array}{l}\text { Non } \\
\text { peroxide } \\
\text { effect }\end{array}$ & $\begin{array}{l}\text { Peroxide } \\
\text { effect }\end{array}$ & Osmolarity & pH 3 & pH 7 & pH 9 & $\begin{array}{l}\text { Bactericidal } \\
\text { bacteriostatic } \\
\text { effect }\end{array}$ \\
\hline & \multicolumn{8}{|c|}{ S. aureus } \\
\hline Z. & $100^{\mathrm{b}}$ & $52.05^{\mathrm{a}}$ & $47.95^{\mathrm{b}}$ & $18.55^{\mathrm{a}}$ & $100^{c}$ & $76.29^{a}$ & $98.70^{\mathrm{b}}$ & bactericidal \\
\hline E. & $94.46^{\mathrm{a}}$ & $71.35^{\mathrm{b}}$ & $23.11^{\mathrm{a}}$ & $76.63^{\mathrm{b}}$ & $100^{c}$ & $99.70^{\mathrm{b}}$ & $100^{c}$ & bacteriostatic \\
\hline \multicolumn{9}{|c|}{ P. aeruginosa } \\
\hline Z. & $92.97^{\mathrm{a}}$ & $81.75^{\mathrm{b}}$ & $11.22^{\mathrm{a}}$ & $13.72^{\mathrm{a}}$ & $100^{\mathrm{c}}$ & $59.28^{\mathrm{a}}$ & $97.66^{\mathrm{c}}$ & bactericidal \\
\hline E. & $100^{\mathrm{b}}$ & $35.71^{\mathrm{a}}$ & $64.29^{\mathrm{b}}$ & $51.69^{b}$ & $91.62^{b}$ & $100^{\mathrm{b}}$ & $100^{c}$ & bactericidal \\
\hline \multicolumn{9}{|l|}{ E. coli } \\
\hline Z. & $100^{\mathrm{a}}$ & $66.10^{\mathrm{a}}$ & $33.90^{\mathrm{a}}$ & $17.00^{\mathrm{a}}$ & $100^{\mathrm{c}}$ & $56.25^{\mathrm{a}}$ & $100^{\mathrm{c}}$ & bactericidal \\
\hline E. & $100^{\mathrm{a}}$ & $60.08^{a}$ & $39.92^{\mathrm{a}}$ & $41.60^{\mathrm{b}}$ & $100^{\mathrm{c}}$ & $69.20^{\mathrm{b}}$ & $100^{\mathrm{c}}$ & bactericidal \\
\hline
\end{tabular}

Although $P$. aeruginosa is the least sensitive strain, but honeys action takes a fundamental importance when we know that more of $50 P$. aeruginosa strains are incriminated in ear infections, diabetic foot ulcers and infected cutaneous burns, as confirmed by Mullai and Menon (2005), (Mullai and Menon, 2007) in their work on 152 Pseudomonas isolates from hospitalized patients; and Cooper $\boldsymbol{e t}$ al. (2002a) in their survey on alternative treatments of the infected burns.

Osmolarity effect proves to be important in most cases, for E. coli it represents about $29.3 \%$ of the total AMA, this last rises to $32.7 \%$ for P. aeruginosa and $47.6 \%$ for $S$. aureus, which is not negligible.

The antimicrobial effect appears to be maximal in acidic or basic environment We notice that Ziziphus honeys show a bactericidal action for all studied strains, but this activity is very sensitive to $\mathrm{pH}$ changes, it is maximal mainly in an acidic environment ( $\mathrm{pH} 3$ ).

Euphorbia honeys are bactericidal for E. coli and P. aeruginosa (Gram -) but only bacteriostatic for $S$. aureus $(\mathrm{Gram}+)$, its action is divided between peroxides and non-peroxide fractions. The particularity of these honeys is that the osmolarity plays a major role with an average of $56.6 \%$ of total AMA, but remains unchanged at different medium $\mathrm{pH}$.

It is necessary to signal that strain behaviors are complex, according to a Bulgarian survey (Khristov and Mladenov, 1961) working on 50\% honeys solutions and 12 bacterial species, it was Gram+ strains that are first killed (after $1 \mathrm{~h}$ exhibition) with a complete bactericidal action between 3 and $24 \mathrm{~h}$, whereas Gram - species are more resistant and begin to die after 4 to $6 \mathrm{~h}$, with a complete extermination in approximately $48 \mathrm{~h}$.

ABOUL ELA, M. A., EL SHER, N. S., GHANEM, N. B. 1996. Antimicrobial evaluation and chromatographic analysis of some essential fixed oils. Pharmazie, 51(12), 993-994

AL KHALIFA, A. S., AL ARIFY, I. A. 1999. Physicochemical characteristics and pollen spectrum of some Saudi honey. Food chemistry, 67, 21 25.http://dx.doi.org/10.1016/S0308-8146(99)00096-5

AL SOMAL, N., COLEY, K. E., MOLAN, P. C., HANCOCK, B. M. 1994 Susceptibility of Helicobacter pylori to the antibacterial activity of manuka honey. Journal of the Royal Society of Medicine 87, 9-12

BABA AISSA, F. 1999. Les plantes médicinales en Algérie, Alger, Bouchène et Addiwan.

BOGDANOV, S. 1984. Characterisation of antibacterial substances in honey. Lebensmittel-Wissenschaft und-Technologie, 17, 74-76

BOGDANOV, S. 1997a. Harmonized methods of the international honey commission. Apidologie, special issue, 25

BOGDANOV, S. 1997b. Nature and origin of the antibacterial substances in honey. LWT - Food Science and Technology, 30, 748-753

BOGDANOV, S., BLUMER, P. 2001. Propriétés antibiotiques naturelles du miel. Revue suisse de recherches apicoles, 98(3), 107-114

BOGDANOV, S., JURENDIC, T., SIEBER, R., GALLMANN, P. 2008. Honey for nutrition and health: a review. $J$ Am Coll Nutr, 27, 67789.http://dx.doi.org/10.1080/07315724.2008.10719745

BRADY, N. F., MOLAN, P. C., HARFOOT, C. G. 1997. The sensivity of dermatophytes to the antimicrobial activity of Manuka honey and other honey. Pharm. Sci., 2, 1-3.http://dx.doi.org/ 10.1111/j.2042-7158.1996.tb00540.x

BRASSON, N. J., GOBLER, S. R. 2008. Antimicrobial activity of two South African Honeys produced from indigenous Leucospermum Cordifolium and Erica species on selected microorganisms. BMC Complement Altern. Med., 15, 841.http://dx.doi.org/ 10.1186/1472-6882-8-41

CHAKIR, A., ROMANE, A., MARCAZZAN, G. L., FERRAZZI, P. 2011. Physicochemical properties of some honeys produced from different plants in

Morocco Arabian Journal

Chemistry.http://dx.doi.org/10.1016/j.arabjc.2011.10.013

\section{CONCLUSION}

The study of the antimicrobial potentialities of both honey types (Z. lotus and E. bupleuroides) revealed good inhibitory effect on the studied bacterial strains ( $E$. coli, $S$. aureus and $P$. aeruginosa) but no antifungal effect tested on $C$. albicans; Leading to weak uses in Candida fungal diseases.

Euphorbia honeys presented better performances (dose/effect), but remain especially active thanks to its osmolarity and phenolic acids and show only bacteriostatic effect on $S$. aureus (Gram positive). Ziziphus honeys show total bactericidal effect at pH 3 especially against G- strains. A big heterogeneity was observed within the same honey group, indicating that the antimicrobial effect of a honey is tributary of an important number of factors (visited flora, pedoclimatic conditions, harvest year, etc.). Finally, we can affirm today that these special honeys present interesting possibilities for use in soft medicine against these bacterial infections and can advantageously be used in some human pathologies.

Acknowledgments: The authors thank the staff of CRD-SAIDAL, the fraud repression laboratory (Al Harrach), the pedagogic laboratories of department of food technology (DTA) and the all the staff of food research laboratory (LRTA). This research did not receive any specific grant from funding agencies in the public, commercial, or not-for-profit sectors.

\section{REFERENCES}

COOPER, R. 2001. How do honey heal wounds. In: JONES, P. M. A. R. (ed.) Honey and healing. cardiff, UK: International bee research association. COOPER, R. A., MOLAN, P. C., HARDING, K. G. 2002a. The sensitivity to honey of Gram-positive cocci of clinical significance isolated from wounds. $J$ Appl Microbiol, 93, 857-63.http://dx.doi.org/10.1046/j.1365-2672.2002.01761.x COOPER, R. A., MOLAN, P. C., HARDING, K. G. 2002b. The sensitivity to honey of Gram-positive cocci of clinical significance isolated from wounds. Journal of Applied Microbiology 93, 857-863. http://dx.doi.org/10.1046/j.13652672.2002.01761.x

DUSTMAN, J. H. 1979. Antibacterial effect of honey. Apiacta 14(1), 7-11

ESCRICHE, I., KADAR, M., JUAN-BORRAS, M., DOMENECH, E. 2014 Suitability of antioxidant capacity, flavonoids and phenolic acids for floral authentication of honey. Impact of industrial thermal treatment. Food Chem, 142, 135-43.http://dx.doi.org/10.1016/j.foodchem.2013.07.033

HADERBACHE, L., BOUSDIRA, M., MOHAMMEDI, A. 2013. Ziziphus Lotus and Euphorbia bupleuroides Algerian Honeys. World Applied Sciences Journal 1536-1543.http://dx.doi.org/10.5829/idosi.wasj.2013.24.11.7525

HALAWANI, M., SHOHAYEB, M. 2011. Shaoka and sidr honeys surpass in their antibacterial activity local and imported honeys available in Saudi markets against pathogenic and food spoilage bacteria. Australian journal of basic and applied sciences, 5 (4), 187-191

JAGANATHAN, S. K. 2011. Can flavonoids from honey alter multidrug $\begin{array}{llll}\text { resistance? } & \text { Med Hypotheses, } & \text { 76, }\end{array}$ 7.http://dx.doi.org/10.1016/j.mehy.2010.12.011

JE-RUEI, L., YI-LING, Y., TING-YU, L., YUN-WEN, W., CHI-CHUNG, P. 2013. Effect of floral sources on the antioxidant, antimicrobial, and antiinflammatory activities of honeys in Taiwan. Food Chemistry, 139, 938943.http://dx.doi.org/ 10.1016/j.foodchem.2013.02.015

KHOSVARI, A., HOJJATOLLAH, S., FARZAD, K. 2008. Fungicidal potential of different Iranian honeys against some pathogenic Candida species. Journal of apicultural research and bee world, 47 (4), 256260.https://dx.doi.org/10.1080/00218839.2008.11101471

KHRISTOV, G., MLADENOV, S. 1961. Propriétés antibactériennes du miel. Comptes rendus de l'Académie bulgare des sciences, 14(3), 303-306 
KUMAR, A., GILLA, J. P. S., BEDIA, J. S., MANAVB, M., ANSARIC, M. J. and WALIAD, G. S. 2018. Sensorial and physicochemical analysis of Indian honeys for assessment of quality and floral origins. Food Research International, 108, 571-583. http://dx.doi.org/10.1016/j.foodres.2018.04.005 LECLERC, H., IZAERD, D., HUDDON, M., WALTER, P., JAKUBE, E. 1993. Préparation des suspensions microbiennes. In: DUNOD (ed.) Microbiologie générale. Paris.

LIN, S. M., MOLAN, P. C., CURSONS, R. T. 2009. The in vivo susceptibility of campylobacter Spp. To the antibacterial effect of manuka honey. Eur. J. Clin. Microbiol. Infect. Dis., 28, 339-344. http://dx.doi.org/10.1007/s10096-008-0630$\underline{3}$

MAJTAN, J., BOHOVA, J., GARCIA-VILLALBA, R., TOMAS-BARBERAN, F. A., MADAKOVA, Z., MAJTAN, T., MAJTAN, V., KLAUDINY, J. 2013. Fir honeydew honey flavonoids inhibit TNF-alpha-induced MMP-9 expression in human keratinocytes: a new action of honey in wound healing. Arch Dermatol Res, 305, 619-27.http://dx.doi.org/10.1007/s00403-013-1385-y

MARGHITAS, L. A. I., DEZMIREAN, D., ADELA, M., OTILIA, B., LASLO, L., BOGDANOV, S. 2009. Physic-chemical and bioactive properties of different floral origin honeys from Romania. Food Chemistry, 112, 863867.http://dx.doi.org/ 10.1016/i.foodchem.2008.06.055

MEDA, A., LAMIEN, C. E., ROMITO, M., MILLOGO, J., NACOULMA, O G. 2005. Determination of the total phenolic, flavonoid ans proline contents in Burkina Fasan honey, as well as their radical scavenging activity. Food chemistry, 91, 571-577. https://dx.doi.org/10.1016/j.foodchem.2004.10.006

MEENA, M. R., SETHI, V. 1994. Antimicrobial activity of essential oils from spices. Journal of food science and technology, 31, 68-70

MEKIOUS, S., HOUMANI, Z., BRUNEAU, É., MASSEAUX, C., GUILLET, A., HANCE, T. 2015. Caractérisation des miels produits dans la région steppique de Djelfa en Algérie. Biotechnol. Agron. Soc. Environ. 19(3)

$221-231$

MOLAN, P. C. 1992a. The antibacterial activity of honey. 1 . The nature of the antibacterial activity. Bee world, 73(1), 5-28

MOLAN, P. C. 1992b. The antibacterial activity of honey. 2. Variation of the potency of the antibacterial activity. Bee world, 73(2), 59-76

MONIRUZZAMAN, M., SULAIMAN, S. A., AZLAN, S. A., GAN, S. H. 2013. Two-year variations of phenolics, flavonoids and antioxidant contents in acacia honey. Molecules, 18, 14694-710.http://dx.doi.org/10.3390/molecules181214694

MULLAI, V., MENON, T. 2005. Antibacterial activity of honey against Pseudomonas aeruginosa. Indian journal of pharmacology, 37(6), 403405.http://dx.doi.org/10.4103/0253-7613.19082

MULLAI, V., MENON, T. 2007. Bactericidal activity of different types of honey against clinical and environmental isolates of Pseudomonas aeruginosa. $J$ Altern Complement Med, 13, 439-41.http://dx.doi.org/10.1089/acm.2007.6366

MUNDO, M. A., PADILLA-ZAKOUR, O. I., WOROBO, R. W. 2004. Growth inhibition of foodborne pathogens and food spoilage organisms by select raw honeys. International Journal of Food Microbiology, 97, 1-8. http://dx.doi.org/10.1016/j.ijfoodmicro.2004.03.025

PATEL, R. V., THAKER, V. T., PATEL, V. K. 2011. Antimicrobial activity of ginger and honey on isolates of extracted carious teeth during orthodontic treatment. Asian Pacific Journal of Tropical Biomedicine, S58S61.https://dx.doi.org/10.1016/S2221-1691(11)60124-X

QUEZEL, P., MÉDAIL, F. 2003. Ecologie et biogéographie des forets du bassin méditerranéen. Collection environnement. Paris: Lavoisier.

REVATHY, V., BANERJI, S. A. 1980. A preliminary study of antibacterial properties of indian honey. Indian journal of biochemistry and biophysics, 17 (supplement $\mathrm{n}^{\circ} .242$ ), 62

SALOMON, D. 2010. Le miel : de Noé aux soins de plaies. Rev. Med. Suisse, 6, 871-874

VON DER OHE, W., PERSANO ODDO, L., PIANA, M. L., MORLOT, M., MARTIN, P. 2004. Harmonized methods of melissopalinology. Apidologie, 35, S 18-S 25.https://dx.doi.org/10.1051/apido:2004050

WILLIX, D. J., MOLAN, P. C., HARFOOT, C. G. 1992. A comparison of the sensitivity of wound infecting species of bacteria to the antibacterial activity of manuka honey and other honey. Journal of Applied Bacteriology, 73, 388-394. https://dx.doi.org/10.1111/j.1365-2672.1992.tb04993.x

ZAGHLOUL, A. A., EL-SHATTAWY, H. H., KASSEM, A. A., IBRAHIM, E. A., REDDY, I. K., KHAN, M. A. 2001. Honey, a prospective antibiotic: extraction, formulation, and stability. Pharmazie, 56, 643-7

ZAHOOR, M., NAZ, S., SANGEEN, M. 2014. Antibacterial, antifungal and antioxidant activities of honey collected from Timergara (Dir, Pakistan). Pak $J$ Pharm Sci, 27, 45-50

ZERROUK, S., SEIJO, M. C., ESCUREDO, O., RODRÍGUEZ-FLORES, M. S. 2017. Characterization of Ziziphus lotus (jujube) honey produced in Algeria. Journal of Apicultural Research, 57, 166-

174.http://dx.doi.org/10.1080/00218839.2017.1399663 